\title{
Buybacks Versus Dividends
}

\section{Favorable regulatory and tax treatment of buybacks is misguided and should be reformed}

BY RAJAT WADHWANI, CFA

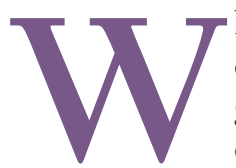
hen a company generates profits and free cash flow, management can invest in growth, retire debt, and distribute excess cash to shareholders. To distribute cash, managers may choose between two methods - dividends or stock buybacks. (U.S. managers may choose not to distribute excess cash because U.S. corporate laws do not currently mandate a certain level of distribution.)

Stock buybacks and dividends are economically equivalent transactions. Each is a mechanism to provide a payoff to the investor. Dividends and share repurchases are indistinguishable in terms of the reduction of free cash flow or the costs of creditor exploitation. The assumption is that companies will ensure that the use of excess cash to buy back stock or pay out dividends does not come at the cost of internal projects or lead to a suboptimal weightedaverage cost of capital of the firm.

Given the economic equality of the two methods of distribution, what motivates U.S. companies to select one over the other, and is one method more efficient than the other?

Dividend increases are viewed by analysts and investors as a stronger form of assurance that management believes the company has the ability to generate adequate excess cash to service the enhanced levels of dividend commitments. Dividends tend to be "sticky" — that is, they raise investor expectations. This effect makes managers reluctant to raise dividends immediately because they worry about not being able to maintain the high dividend level in the future. Empirical studies (Petit 1972, Aharony and Swary 1980, Brickely 1983, and Kalay and Loewenstein 1986) suggest that the real signal to the stock market is not the absolute level of dividends but a change in the level of dividends. Stock and industry sectors tend to trade within a dividend yield range commensurate with the nature of business, expected growth rate, and returns expected by investors. Higher dividend levels tend to increase the dividend yields, thus leading to an increase in stock price.

Dividends are a popular way of judging a company's ability to distribute wealth consistently. According to Standard \& Poor's, the dividend component was responsible for 44 percent of total return for the S\&P 500 over the past 80 years. During the same period, returns with dividend reinvestment (if all dividends had been reinvested) were eight times the returns without dividend reinvestment. Hence, superiority of dividends as a component of overall return cannot be discounted. The dividend component is the most consistent of the total return component. Dividends not only dwarf growth, inflation, and changing valuation levels when those factors are considered separately but also when they are considered in combination. Over the past 200 years, the average annual return for U.S. equities has been 7.9 percent-with 5 percent coming from dividends, 1.4 percent from inflation, 0.6 percent from falling yields and rising valuations, and 0.8 percent from real growth in dividends (Arnott 2003).

Because stock buybacks tend to provide a more flexible mechanism for distributing cash to shareholders, managers prefer them to increasing dividends. The time frames of buyback plans are open ended, and some plans are announced but never take place at all. Moreover, the markets tend not to have a negative response in cases in which a firm fails to complete a previously announced open-market buyback program. The lag between buyback announcements and actual repurchases makes hard numbers difficult to ascertain. There are many anecdotal examples of companies not following through on buyback announcements. For example, in the weeks following the October 1987 stock market crash, some companies announced buybacks in a show of support for their stocks but didn't follow through for one reason or another. From 1985 to 1998, stock buyback programs ballooned from 196 company-announced programs valued at a total of US $\$ 20$ billion to 1,919 company-announced programs valued at US\$225 billion, according to Securities Data Corporation. In 1998, stock-repurchase activity surpassed one-quarter of total business investment for all firms in the United States, according to the U.S. Congress's economic indicators ${ }^{1}$ for that year, and in 1999, the dollar value of stock-repurchase activity exceeded the combined level of R\&D investments by S\&P 500 companies. $^{2}$

Several motivations may lead companies to favor stock buybacks over dividends: tax arbitrage, increase in earnings per share, signaling-information asymmetry, a perception that the stock is undervalued, shareholder appeasement, and stock- and options-based compensation.

TAX ARBITRAGE. Although tax arbitration is one of the commonly cited motivations for buyback programs, the value of such arbitrage has long been debated, chiefly because certain payout policies are accompanied by unfavorable income-tax consequences for shareholders. According to "clientele theory," however, a company

1 "Business investment" in this case refers to equipment and software, not structures. "Economic indicators" refers to the monthly compilation prepared for the Joint Economic Committee by the Council of Economic Advisers, which includes economic information on prices, wages, production, business activity, purchasing power, credit, money, and federal finance.

2 The data represent a period when stock buybacks reached a significant level relative to business investments and R\&D activities. 
D buying back its own stock can reflect shareholder preferences in its distribution by offering multiple options, including turning one's investment into cash (tendering to repurchase offer) or holding out for future capital gains (remaining as shareholders). Thus, only the shareholders who have a cash preference at the time a repurchase is announced will sell their shares to the company, and the increase in overall shareholder wealth will be reflected in the stock price as a result of stock buybacks. The reduction in taxation on dividends enacted in 2003 did make dividend distribution attractive, but the reduced tax on dividends is expected to expire in 2010.

The two benefits of stock buybacks make them more tax efficient than dividend distribution. First, taxes are deferred until the stock is actually sold. Second, in the absence of transaction costs, investors have the ability to offset capital gains against capital losses. Putting dividends on par with the tax efficiency of stock buybacks would require a change in the tax code allowing investors to defer taxes on dividends by investing in dividend reinvestment plans (DRIPs) and to permit investors to use dividend income to offset capital losses (with both provisions being subject to certain exceptions necessary to close any obvious loopholes). These changes would eliminate the tax arbitrage between dividends and stock buybacks.

INCREASED EARNINGS PER SHARE. Because stock buybacks reduce the number of shares outstanding, they result in increased earnings per share. Of course, this improvement is superficial because a stock buyback does not enhance a firm's balance sheet or its industry position relative to competitors. A buyback is simply an exchange between the corporate cash account and shares outstanding. The cost of buying the shares is exactly offset by the value of the reduced number of shares outstanding, which means the value per share of the remaining shares is not affected. Furthermore, if the increase in earnings per share is not accompanied by an increase in total income, the credibility of the signal of improved future cash flow from superior operating performance will be in doubt.

To increase transparency for operations, companies should be required to report the increase in earnings per share both before and after buyback. Although this information is accessible by comparing the increase in net income over two periods, the earnings per share reported (and commonly used for pricing stock and projecting stock price) is not as transparent as before-and-after reporting.

SIGNALING-INFORMATION ASYMmetrY. Proponents of signaling-information asymmetry theory argue that stock buybacks can enhance the market's informational efficiency by conveying valuable information to investors, even if a particular buyback program has no effect on a particular firm's intrinsic value. In other words, given the informational asymmetry that exists between entrepreneurs and investors, stock buybacks may be viewed as a signaling tool for delivering to the market soft information normally available only to managers, such as the expecta- tion of profitable investment opportunities in the future. The advantage of using buyback programs as a potential signaling mechanism (rather than simply sharing the information) is that buybacks avoid the divulgence of proprietary or other firm-specific information, the value of which might be dissipated through dissemination to competitors. The same kind of signaling can be accomplished by increasing dividends, which indicates confidence in generating adequate cash flow.

PERCEPTION OF STOCK BEING UNDERVALUED. Stock buybacks are relatively common when a company's stock is perceived as being undervalued, because an effective way to bolster the price of common stock is for the company to repurchase its own stock on the open market. But the company's management is hired to generate profits from operations, not to invest in stock buybacks on behalf of shareholders. Other means of communication should be used to to convey management's perspective when the stock is believed to be undervalued.

SHAREHOLDER APPEASEMENT. Two attributes of buybackplan announcements suggest that they serve as mollification devices. First, announcements typically lead to a positive market reaction, demonstrating that stock repurchase programs appeal to shareholders. Second, buyback announcements give a company flexibility, because the actual open-market buybacks are exercised at management's discretion. The surge in buybacks to bolster share prices could be interpreted as management's attempt to use company resources to appease shareholders by showing intent to return cash to shareholders, irrespective of whether management ever follows through on its announced intent. To pursue long-term strategies, management needs to be assured of tenure, and appeasing shareholders in the short term can help management achieve a sense of job security. Failure to keep shareholders satisfied presents the possibility of significant hazards, including hostile takeovers; intervention by vigilant, professional money managers; involuntary executive replacement; and loss of potential gains from stock options.

STOCK- AND OPTIONS-BASED COMPENSATION. Stock buybacks have a direct impact on management compensation paid out in the form of stock and options. Agency theory has made this mode of compensation more popular. A basic premise of agency theory is that the separation between owners and managers that characterizes the modern corporation creates a potential conflict of interest that may result in managers engaging in behaviors that are inconsistent with shareholder interests. Even though all shareholders may benefit from stock buybacks, managers stand to gain if the buyback augments the stock price to a level that enables managers to exercise stock options. The value of stock-option pay typically depends entirely on the increase in the company's share price. Consequently, option pay can motivate executives to contemplate all the methods that might lead to an increase in stock price. 


\section{Conclusion}

Companies are not primarily in the business of buying their own stock but instead are expected to create wealth through the normal course of running their business. If firms with abundant capital have limited wealth-maximizing channels, they should distribute the cash to shareholders via dividends. Managers are very likely to overvalue their firm's stock price and complain that the market undervalues their firm instead of seriously facing the reality that the valuation may be correct.

Economists have suggested various advantages of share repurchases, such as the conveyance of valuable information to the equity market and the reduction of agency costs associated with free cash flows. Consistent with these putative advantages, corporate laws and securities regulations in the United States have been generous toward share buybacks. But the expected benefit of conveying soft information regarding company value may be an illusion unless the informational efficiency of the market is guaranteed.

The appeal of repurchases stems from the fact that managers have an incentive to appease shareholders to keep their tenure. Further, managers who hold stock options do not share in the dividends paid by the firm but can enjoy the increase in value reflected in the stock price. The stock price reaction also explains the managerial incentive to choose buybacks rather than paying dividends because the stock price is related to managerial compensation.

The tax heterogeneity, notwithstanding the transaction costs, does make stock buybacks more efficient than dividends. One way to address the tax arbitrage is to allow tax deferral on DRIPs. Not only would such a change put dividends on a par with stock buybacks, but it also would make cash distribution transparent and address inefficiencies that accompany stock buybacks. Alternatively, the inescapable conclusion is that stock buybacks should be subjected to a more restrictive legal framework.

Rajat Wadhwani, CFA, is senior vice president of technology at Bank of America and a member of the New York Society of Security Analysts.

\section{RECOMMENDED RESOURCES}

R. Petit, "Dividend Announcements, Security Performance, and Capital Market Efficiency," Journal of Finance (1972).

J. Aharony and L. Swary, "Quarterly Dividend and Earnings Announcements and Stockholders' Returns: An Empirical Analysis," Journal of Finance (1980).

J. Brickley, "Shareholder Wealth, Information Signaling and the Specially Designated Dividend: An Empirical Study," Journal of Financial Economics (1983).

A. Kalay, and U. Loewenstein, "The Information Content of the Timing of Dividend Announcements," Journal of Financial Economics (1986).

Robert D. Arnott, "Editor's Corner: Dividends and the Three Dwarfs," Financial Analysts Journal (March/April 2003). (www.cfapubs.org).

\title{
This Chair demands that you take a stand.
}

\section{The ING DIRECT Chair in Finance}

Bold ideas change the world. But if a new idea in finance is to be meaningful, it should benefit everyone, not just the few. Because innovation should be about more than a new formula for pricing derivatives; it should be about taking a stand to create positive change for all.

That's where you come in.

The Richard Ivey School of Business seeks candidates at the rank of Professor, or senior Associate Professor for the ING DIRECT Chair in Finance. As Chair you will take a leadership position and further distinguish the School as a world-class source of relevant, applied research and thought leadership in finance and financial innovation.

You will bring together expertise from across the School, as well as The University of Western Ontario to implement new ideas and address challenges confronting today's senior executives.

Your research won't sit on a shelf. It will be meaningful for finance practitioners, and relevant in Ivey's real-world classroom case discussions. You will be a key contributor at Canada's premier business school, globally recognized for the quality of its management education and research.

Candidates at the rank of Professor, or senior Associate Professor, are invited to find out more about this opportunity by visiting www.ivey.uwo.ca/ingdirectchair

ING DIRECT save your money ${ }^{\circledR}$

\author{
a registered trademark of ING Bank of Canada.
}

